\title{
PENGARUH NET PROFIT MARGIN, RETURN ON ASSET DAN RETURN ON EQUITY TERHADAP PERUBAHAN LABA PERUSAHAAN (Studi Kasus pada Perusahaan Manufaktur Sektor Industri Makanan dan Minuman yang terdaftar di Bursa Efek Indonesia Tahun 2013 - 2018)
}

\author{
Saraswati Dewi ${ }^{1}$, Alean Kistiani H S ${ }^{2}$, Yunita Niqrisah Dwi Pratiwi ${ }^{3}$ \\ saraswatidewi08952@gmail.com \\ Universitas Boyolali
}

\begin{abstract}
ABTRACT
Every company has a desire to make a profit in every production. In addition, the wider community measures the success of the company based on the company's ability to earn profits seen from the company's performance, but not only that the success of a company is also seen from the achievement of the company's vision and mission goals. One alternative to find out the financial information generated is useful by predicting changes in earnings. Including financial conditions in the future is analyzing financial ratios.

This study aims to determine the effect of Net Profit Margin, Return On Assets and Return On Equity on changes in company profits in food and beverage Sub Sector Companies Listed on the Indonesia Stock Exchange Period 2013 2018.

The type of data used is secondary data, namely regarding financial statements. The sampling technique used was purposive sampling of 13 companies. All data were analyzed by multiple linear regression analysis, classic assumption test, $t$ test and coefficient of determination. The results of the research show partially the variables that influence the change in company profits are only Net Profit Margin. And simultaneously the independent variable has no effect on the dependent variable.
\end{abstract}

Keywords: Net Profit Margin, Return On Asset, Return On Equity, changes in company profits.

\section{PENDAHULUAN}

\subsection{Latar Belakang}

Setiap perusahaan
memiliki keinginan untuk
memperoleh laba dalam setiap
produksinya. Disamping itu,
masyarakat luas mengukur
keberhasilan
berdasarkan perusahaan
perusahaan dalam memperoleh
laba yang dilihat dari kinerja

perusahaan. Salah satu alternatif untuk mengetahui informasi keuangan yang dihasilkan bermanfaat untuk memprediksi perubahan laba. Termasuk kondisi keuangan dimasa yang akan datang adalah menganalisis rasio keuangan. Return On Assets merupakan rasio keuangan perusahaan yang berhubungan 
dengan profitabilitas mengukur kemampuan perusahaan menghasilkan keuntungan atau laba pada tingkat pendapatan, modal saham tertentu dan aset. Kita dapat menilai apakah perusahaan telah efisien dalam menggunakan aktivanya dalam kegiatan operasi untuk menghasilkan keuntungan dengan mengetahui ROA tersebut (Hanafi dan Halim, 2003:27).

Return On Assets juga dipengaruhi oleh Net Profit Margin, yang digunakan untuk mengukur rupiah laba bersih yang dihasilkan oleh setiap satu rupiah laba bersih yang dihasilkan oleh setiap satu rupiah penjualan dan mengukur seluruh efisiensi baik produksi, administrasi, pendanaan, penentuan harga maupun manajemen pajak. Semakin besar nilai NPM perusahaan, maka kinerja perusahaan akan semakin produktif, sehingga akan meningkatkan kepercayaan investor untuk menanamkan modalnya pada perusahaan tersebut.

Perubahan kenaikan atau penurunan itu akan mempengaruhi kebijakan keuangan untuk kegiatan selanjutnya, seperti kebijakan mengenai deviden, pembayaran utang, penyisihan, investasi, dan menjaga kelangsungan kegiatan perusahaan.

Perusahaan makanan dan minuman dipilih karena memegang peranan penting dalam memenuhi kebutuhan konsumen. Kebutuhan masyarakat akan produk makanan dan minuman akan selalu ada karena merupakan salah satu kebutuhan pokok. Didasarkan pada kenyataan tersebut, perusahaan makanan dan minuman dianggap akan terus survive. Industri makanan dan minuman adalah industri yang perkembangannya baik, pertumbuhan yang positif, sangat cepat dan akan selalu ada karena merupakan salah satu kebutuhan pokok. Berdasarkan uraian di atas, untuk mengetahui sejauh mana pengaruh rasio keuangan terhadap laba perusahaan, penulis memilih judul "Pengaruh Net Profit Margin, Return On Asset dan Return On Equty Terhadap Perubahan Laba Perusahaan (Studi Kasus pada Perusahaan Manufaktur Sektor Industri Makanan dan Minuman yang terdaftar di Bursa Efek Indonesia Tahun 2013 - 2018).

\section{TINJAUAN PUSTAKA}

\subsection{Landasan Teori}

\section{Rasio Profitabilitas}

Pengertian profitabilitas menurut Mamduh M. Hanafi (2012:81) "Rasio ini mengukur kemampuan perusahaan menghasilkan keuntungan (profitabilitas) pada tingkat penjualan, aset, dan modal saham yang tertentu.

\section{Return On Equity (ROE)}

Pengertian Return On Equity (ROE) menurut Sartono (2012:124) ROE yaitu: "Mengukur kemampuan perusahaan memperoleh laba yang tersedia bagi pemegang 


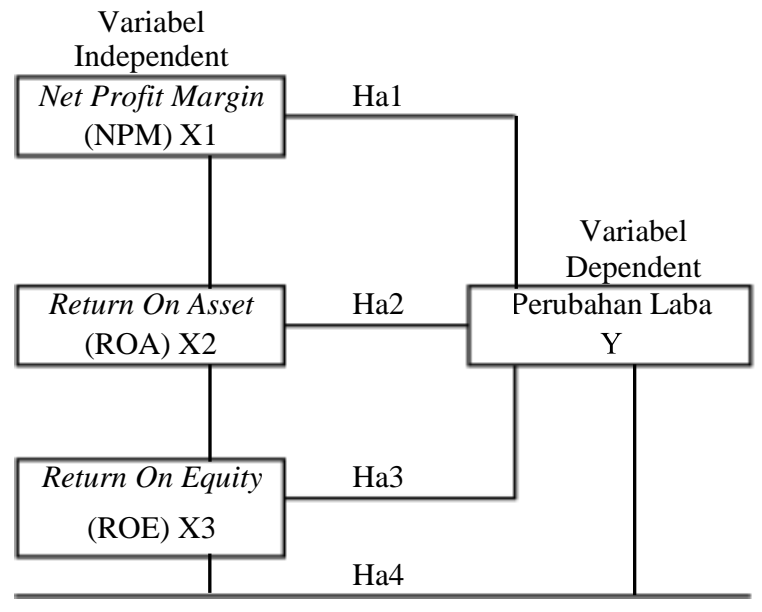

saham perusahaan. Rasio ini juga dipengaruhi oleh besar kecilnya utang perusahaan, apabila proporsi utang besar maka rasio ini akan besar".

\section{Return on Assets (ROA)}

Menurut Hanafi dan juga Halim (2003 : 27), Return on Assets (ROA) adalah rasio keuangan perusahaan yang terkait dengan potensi keuntungan mengukur kekuatan perusahaan membuahkan keuntungan atau juga laba pada tingkat pendapatan, aset dan juga modal saham spesifik.

\section{Net Profit Margin (NPM)}

Menurut Prastowo dan Juliati (2003:91) margin laba bersih atau Net Profit Margin,berguna untuk mengukur rupiah laba bersih yang diperoleh dari setiap satu rupiah penjualan dan kemudian untuk mengukur efisien, biaya produksi, administrasi, pemasaran, pendanaan, penentuan harga, maupun pengelolaan pajak.

\section{Pertumbuhan Laba}

Menurut Simorangkir (1993) dalam Hapsari (2003)
Pertumbuhan laba yaitu perubahan presentase kenaikan laba yang diperoleh perusahaan.

\subsection{Kerangka Pemikiran}

\subsection{Hipotesis Penelitian}

Pengaruh Net Profit Margin (NPM) terhadap pertumbuhan laba perusahaan

Net Profit Margin (NPM) merupakan rasio yang digunakan untuk mengukur seluruh efektivitas dalam menghasilkan penjualan dan biaya pengendalian (Ikhsan, 2009: 102). Net Profit Margin (NPM) merupakan perhitungan terakhir laba yang didapatkan setelah dikurangi pajak atau dapat dikatakan sebagai laba bersih perusahaan atas penjualan. Semakin besar nilai laba bersih, maka semakin besar pula nilai Net Profit Margin (NPM).

Pengaruh Return On Asset (ROA) terhadap pertumbuhan laba perusahaan

Return On Asset (ROA) merupakan suatu ukuran kemampuan perusahaan mengelola laba bersih berdasarkan tingkat aset tertentu. Semakin kecil nilai Return On Asset (ROA) semakin kurang baik, demikian pula sebaliknya. Artinya rasio ini digunakan untuk mengukur efektifitas dari keseluruhan operasi perusahaan (Kasmir, 2015:202).

Pengaruh Return On Equity (ROE) terhadap pertumbuhan laba perusahaan 
Return On Equity (ROE) atau rentabilitas modal sendiri merupakan rasio untuk mengukur laba bersih sesudah pajak dengan modal sendiri. Rasio ini menunjukkan efisiensi penggunaan modal sendiri. Semakin tinggi rasio ini, semakin baik. Artinya posisi pemilik perusahaan semakin kuat, demikian pula sebaliknya (Kasmir, 2015:204).

Pengaruh NPM, ROA, dan ROE secara simultan terhadap prubahan laba perusahaan

NPM, ROA, dan ROE merupakan komponen dari rasio profitabilitas, rasio ini digunakan untuk menilai kemampuan perusahaan dalam mencari keuntungan. Rasio ini juga memberikan ukuran tingkat efektifitas manajemen suatu perusahaan. Hal ini ditunjukkan oleh laba yang dihasilkan dari penjualan dan pendapatan investasi. Intinya adalah penggunaan rasio ini menunjukkan efisiensi perusahaan.

\section{METODOLOGI PENELITIAN}

Berdasarkan jenis data yang digunakan, penelitian ini merupakan studi empiris pada perusahaan manufaktur yang terdaftar di Bursa Efek Indonesia Tahun 2013 - 2018.

Metode pengumpulan data yang digunakan dalam penelitian adalah dengan riset internet (research online) yang diperoleh melalui situs resmi Bursa Efek Indonesia yaitu http://www.idx.co.id. Data yang digunakan dalam penelitian ini adalah data sekunder dari laporan keuangan. Teknik analisa yang digunakan dalam penelitian ini adalah analisis statistik deskriptif, uji regresi linier berganda, uji asumsi klasik, uji t, uji f dan uji koefisien determinasi.

\section{PENGUJIAN HIPOTESIS}

Hasil analisis data diatas menghasilkan nilai-nilai yang digunakan untuk membuktikan hipotesis dari penelitian, yaitu sebagai berikut:

a. Hipotesis Pertama

Berdasarkan hasil uji $t$ menunjukkan bahwa Sighitudu dari Net Profit Margin kurang dari 0,05 yaitu sebesar 0,016. Sehingga dapat disimpulkan bahwa secara parsial Net Profit Margin berpengaruh terhadap perubahan laba. Return On Asset dan Return On Equity lebih besar dari 0,05 yaitu sebesar 0,163 dan 0,844 . Sehingga dapat disimpulkan bahwa secara parsial Return On Asset dan Return On Equity tidak berpengaruh terhadap perubahan laba.

b. Hipotesis kedua

Berdasarkan uji $\mathrm{F}$ menunjukan bahwa nilai Sighðtuau sebesar 0,099 dan 0,099>0,05

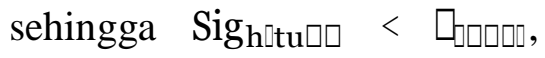
maka dapat disimpulkan bahwa secara bersama - sama variabel indapendent (Net Profit Margin, Return On Asset dan Return On Equity) tidak berpengaruh tarhadap variabel dependen (Perubahan laba).

\section{PENUTUP}

\subsection{Kesimpulan}

$$
\begin{aligned}
& \text { Berdasarkan hasil } \\
& \text { pembahasan diatas dapat } \\
& \text { disimpulkan sebagai berikut: }
\end{aligned}
$$

1. Hasil uji secara parsial menunjukkan bahwa variabel Net Profit Margin (NPM) berpengaruh terhadap perubahan laba perusahaan. 
Sedangkan variabel Return On Asset (ROA) tidak berpengaruh terhadap perubahan laba perusahaan dan Return On Equity (ROE) tidak berpengaruh terhadap perubahan laba perusahaan.

2. Hasil uji secara simultan menunjukkan bahwa Net Profit Margin (NPM), Return On Asset (ROA) dan Return On Equity (ROE) tidak berpengaruh signifikan secara bersama-sama terhadap perubahan laba.

\subsection{Saran}

Berdasarkan kesimpulan yang telah diuraikan diatas, maka penulis mmemberikan saransaran kepada peneliti selanjutnya, yaitu :
1. Diharapkan agar mengembangkan variabel- variabel yang akan diteliti.

\section{DAFTAR PUSTAKA}

Agus Sartono. 2012. Manajemen Keuangan Teori dan Aplikasi. Edisi4. BPFE. Yogyakarta.

Arista Ita. 2014 Pengaruh Profitabilitas Terhadap Pertumbuhan Laba pada Perusahaan Food and Baverages di Bursa Efek Indonesia (BEI). Surakarta: UMS.

Baraja Ibrahim Shara. 2014 Pengaruh Rasio Likuiditas dan Rasio Profitabilitas terhadap Perubahan Laba pada perusahaan manufaktur yang terdaftar di BEI Tahun 2010 - 2011.

Surakarta: UMS
Terdapat banyak variabel rasio profitabilitas yang dapat digunakan dalam memprediksi perubahan laba yaitu Return On Investment, Return On Capital Employed, Return On Sales Ratio, dan margin laba kotor. karena apabila menggunakan lebih banyak variabel tidak menutup kemungkinan akan mendapat kesimpulan yang lebih baik.

2. Diharapkan memperpanjang periode pengamatan agar lebih menggambarkan kondisi keuangan perusahaan dan memperluas sampel, tidak hanya pada perusahaan manufaktur makanan dan minuman saja, tetapi dengan sektor-sektor lain, sehingga dapat diperoleh hasil yang lebih baik.

Brigham dan Houston. 2011. Dasardasar Manajemen Keuangan Buku 1 (Edisi 11). Jakarta : Selemba Empat.

Ghozali, Imam. 2016. Aplikasi Analisis Multivariete Dengan Program IBM SPSS 23 (Edisi 8), Cetakan ke VIII. Semarang: Badan Penerbit Universitas Diponegoro.

Hanafi, Mamduh dan Abdul Halim, 2012. Analisis Laporan Kuangan. Yogyakarta: (UPP) STIM YKPN.

Hanafi, Mamduh dan Abdul Halim. 2003.Analisis Laporan Keuangan. EdisiRevisi. 


\section{Yogyakarta: UPP AMP YKPN.}

Kasmir. 2015 Analisis Laporan Keuangan. Jakarta: PT Raja Grafindo Persada.

Machfoedz, 1994, Pengaruh Rasio Keuangan Terhadap Perubahan Laba, Jurnal Riset Akuntansi Indonesia.

Mardiyanto, Handono, 2009. Intisari Manajemen Keuangan.

Jakarta : Grasindo.

Martono \& Agus Prajitno. 2010. Manajemen Keuangan. Yogyakarta: Ekonisia.

Munawir. 2007. Analisa Laporan Keuangan. Liberty, Yogyakarta.

Munawir. 2010. Analisis Laporan Keuangan (Edisi

4). Yogyakarta : Liberty.

Ismiati Nike, Puspitaningtyas Zarah dan Sisbintari Ika. 2013. Pengaruh Perputaran Modal
Kerja Terhadap Profitabilitas Perusahaan (Studi Pada Perusahaan Manufaktur yang Terdaftar di Bursa Efek Indonesia tahun 2008 2012), Jember.

Prastowo D, Dwi dan Rika Juliaty. 2002.Analisis Laporan Keuangan. EdisiRevisi. Yogyakarta: UPP AMP YKPN.

Sudana, I Made. 2011. Manajemen Keuangan Perusahaan Teori \& Praktik. Jakarta:Erlangga.

Sugiyono. 2016. Metode Penelitian Kuantitatif, Kualitatif, dan $R \& D$. Bandung: Alfabeta.

Referensi melalui Riset Internet (Online Reseacrh)

$\underline{\text { www.idx.co.id }}$ 